\title{
Application of good milking practices: economic impacts and bovine raw milk quality
}

\author{
Aplicação das boas práticas de ordenha: impactos \\ econômicos e qualidade do leite cru bovino
}

Aplicación de las buenas prácticas de ordeño: impactos económicos y calidad de la leche cruda bovina

Évelyn Silva de Melo Soares ${ }^{1}$ Marjorie Toledo Toledo Duarte ${ }^{2}$

Kênia Fátima Carrijo ${ }^{3}$ Marcela de Rezende Costa ${ }^{4}$

${ }^{1}$ Master in Animal Science. PhD student in the Animal Science Program at the Federal University of Mato Grosso do Sul (UFMS), Faculty of Veterinary Medicine and Zootechny (FAMEZ). E-mail: evelynsilvademelo@gmail.com, Orcid: http://orcid.org/0000-0003-4321-2428

${ }^{2}$ Doctor in Veterinary Medicine. Professor at the Federal University of Mato Grosso do Sul (UFMS), of Veterinary Medicine and Zootechny (FAMEZ). E-mail: marjorie.duarte@ufms.br, Orcid: http://orcid.org/0000-0002-7251-1227

${ }^{3}$ Doctor in Veterinary Medicine. Professor at the Federal University of Uberlândia (UFU), Faculty of Veterinary Medicine. E-mail: kenniafcarrijo@yahoo.com.br, Orcid: http://orcid.org/0000-0002-4946-9091

${ }^{4}$ Doctor in Food Technology. Professor at the Federal University of Mato Grosso do Sul (UFMS), Faculty of Pharmaceutic Sciences, Food and Nutrition (FACFAN). E-mail: marcela.rezende@ufms.br, Orcid: http://orcid.org/0000-0002-7784-854X 


\begin{abstract}
The aim of this study was to evaluate the effects of application of the good milking practices on economic aspects as well as on microbiological and sanitary characteristics of raw milk and bovine mammary gland of animals from Sidrolandia/MS farms. A questionnaire was applied to verify the utilization of good milking practices and milk samples of each property were collected from the expansion tanks to evaluate total bacteria and somatic cell counts as well as milk composition and frauds presence, before and after training the farms employees in good milking practices. The farms that adopted the measures of milking hygiene reduced the bacteria and somatic cell counts, what caused increase on milk quality, better mastitis control and greater bonus payment by the industry to the producers. Thus, incorporation of good milking practices promoted positive impacts on socio-economic aspects and milk quality.
\end{abstract}

Keywords: total bacterial count; somatic cell count; food hygiene; milk production.

Resumo: O objetivo desse trabalho foi avaliar os efeitos da aplicação das boas práticas de ordenha em aspectos econômicos e nas características microbiológicas e sanitárias do leite cru e sanidade da glândula mamária de bovinos de fazendas em Sidrolândia/MS. Um questionário foi aplicado para verificar a utilização das boas práticas e amostras de leite foram coletadas dos tanques de expansão de cada propriedade para avaliação das contagens microbiana total e de células somáticas, análises de composição do leite e pesquisa de fraudes, antes e após o treinamento dos funcionários nas boas práticas. As propriedades que adotaram as medidas de higiene reduziram as contagens bacterianas totais e de células somáticas, o que proporcionou um aumento na qualidade do leite, melhor controle da mastite e um incremento na bonificação mensal paga aos produtores pela indústria. Assim, a incorporação das boas práticas promoveu impactos positivos em aspectos socioeconômicos e de qualidade do leite.

Palavras-chaves: contagem bacteriana total; contagem de células somáticas; higiene alimentar; produção leiteira.

Resumen: El objetivo fue evaluar los efectos de la aplicación de las buenas prácticas de ordeño en el aspecto económico y en las características microbiológicas y sanitarias de la leche cruda y de la glándula mamaria de bovinos de propiedades de Sidrolandia/MS. Se aplicó un cuestionario para verificar la utilización de las buenas prácticas y se recogieron muestras de leche de los tanques de expansión de cada propiedad para evaluar los conteos microbianos totales y de las células somáticas, análisis de composición de la leche y de fraudes, antes y después del entrenamiento de los empleados de las propiedades en buenas prácticas. Las estancias que adoptaron las medidas de higiene redujeron los conteos bacterianos totales y de células somáticas, lo que proporcionó un aumento de la calidad de la leche, mejor control de mastitis y un incremento en la bonificación mensual pagada pela industria para los productores. Por lo tanto, la incorporación de las buenas prácticas promovió impactos positivos en los aspectos socioeconómicos y de calidad de la leche.

Palabras clave: recuento bacteriano total; recuento de células somáticas; higiene alimentaria; producción lechera. 


\section{INTRODUCTION}

The consumer market has become increasingly demanding with the quality of products offered, thanks to the understanding of the role of food and its components on health. Quality milk must have chemical composition, somatic cell counts (CCS) and microbiological and sensory characteristics that comply with the parameters required by law.

In this way, hygienic measures to avoid the contamination of the milk must begin at milking and continue until its processing. This can be achieved by good milking practices.

The good milking practices are hygienic measures adopted on farms to obtain the milk through a set of activities. These tasks range from the organization of the property, its facilities, equipment and actions involving humans and animals. Therefore, good milking practices become an alternative to minimize the risk of biological, chemical and physical contaminations at the various stages of the production process; consequently, they supply safe food for industry, which in turn provide quality products to the customers.

Thus, the objective of this study was to evaluate the economic impact and the influence of the application of good practices in the management of milking on microbiological and sanitary characteristics of bovine raw milk and mammary gland in dairy farms.

\section{MATERIAL AND METHODS}

This work was carried out in properties of Sidrolândia city, Mato Grosso do Sul State, Brazil, from March to November 2015. Eight dairy farms participated. The properties were chosen because they did not accomplish the standards of the somatic cell (SCC) and total bacteria (TBC) counts established by Brazilian law, and they deliver milk to a cheese industry in the city of Terenos, Mato Grosso do Sul, under sanitary inspection, which practiced payment and bonifications for quality.

A survey of hygienic practices conventionally used by the producers was conducted from March to June to know the reality of the milk production in these properties, through monitoring and on-site observations of the milking routine, and through the application of a questionnaire on each property as well as the collection of milk samples for laboratory testing. 
The questionnaire was prepared using as a reference the Ordinance n. 368 (BRASIL, 1997) and Normative Instruction n. 62 (BRASIL, 2011), by the Ministry of Agriculture, Livestock and Food Supply (MAPA), with the aim to evaluate the procedures performed in each property before, during and after obtaining the milk, related to the quality of the raw material.

After the questionnaire application and the obtainment of the first analyzes results, a training on hygienic milking and milk quality was designed. The training was held in two days, the first theoretical and the second with practical classes in the corral of one of the participant properties of the study, in June. The properties were visited one by one later in July to solve questions that appeared in the routine.

The milking hygienic practices adopted were: using black mug test for Mastitis; realizing California Mastitis Test (CMT) individually in all the lactating cows at least twice a month; performing the pre- and the afterdipping leaving the solution in contact with the teats for 30 seconds; drying the teats with paper towels before starting the milking process; performing the correct operation and maintenance of the milking machines; applying the indicated protocol for cleaning utensils and milking equipment (product type, solution concentration, circulation rate and water temperature) and following the cattle's dry cycle.

The laboratorial milk analyzes were also carried out after the training, to see if in fact the good practices were implemented in the properties and its interference in the quality of milk produced.

Two samples of raw milk were collected monthly, directly from the expansion tanks of each property. The samples were put in sterile flasks about $40 \mathrm{~mL}$, one containing a tablet of Bronopo ${ }^{\circledR}$ and other with Azidiol ${ }^{\circledR}$, packed in isothermal boxes containing recyclable ice, and transported to the Clinica do Leite Laboratory of ESALQ-USP, in Piracicaba city, São Paulo State, Brazil, member of the Milk Quality Control Laboratories Brazilian Network (RBQL). Samples containing Bronopo ${ }^{\circledR}$ were analyzed by flow cytometry methodology in the electronic counter Somacount $500^{\circledR}$ (BENTLEY INSTRUMENTS, 1994), which provided results of Somatic Cell Count (SCC) and chemical composition. Samples containing Azidiol ${ }^{\circledR}$ were analyzed by flow cytometry methodology in the electronic counter Bactocount- IBC ${ }^{\circledR}$ (BENTLEY INSTRUMENTS, 2004), 
which provided results of total bacteria count (TBC). In the dairy industry laboratory, physicochemical analyzes (titratable acidity, density at $15{ }^{\circ} \mathrm{C}$, fat content by Gerber method, cryoscopic index and protein content by Kjeldahl) and fraud search (chlorides, sucrose, starch, hydrogen peroxide, alkali and formaldehyde) were performed, according to the official methods of the MAPA's Normative Instruction n. 68/2006 (BRASIL, 2006). The data obtained before and after the training were analyzed using Anova test at $5 \%$ significance.

A payment simulation based on the milk quality, as normally used in that dairy industry, was carried out to check the economic effect of the application of the good milking practices in which the properties staff were trained in this study. A fixed base price paid in the state of Mato Grosso do Sul, according to Centro de Estudos Avançados em Economia Aplicada (CEPEA, 2015), was used for comparison to avoid variation due to the months of the year. The payment was calculated taking in count average milk production, SCC and TBC for each herd, with the discount and bonus values normally practiced by the industry (Chart 1 ).

Chart 1 - System of bonus/penalty used to pay for milk quality in the dairy industry

\begin{tabular}{|c|c|c|c|c|c|}
\hline \multicolumn{3}{|c|}{ SCC (cel/ml) } & \multicolumn{3}{|c|}{ TBC (cel/ml) } \\
\hline From & Until & R\$/liter & From & Until & $\mathrm{R} \$ /$ liter \\
\hline \multicolumn{6}{|c|}{ Bonus range } \\
\hline 1,000 & 140,999 & 0.040 & 1,000 & 20,999 & 0.040 \\
\hline 141,000 & 200,999 & 0.030 & 21,000 & 50,999 & 0.030 \\
\hline 201,000 & 300,999 & 0.020 & 51,000 & 80,999 & 0.020 \\
\hline 301,000 & 400,999 & 0.015 & 81,000 & 100,999 & 0.010 \\
\hline \multicolumn{6}{|c|}{ Neutral range } \\
\hline 401,000 & 600,999 & 0 & 101,000 & 500,999 & 0 \\
\hline \multicolumn{6}{|c|}{ Penalty range } \\
\hline 601,000 & 700,999 & -0.010 & 501,000 & 600,999 & -0.016 \\
\hline 701,000 & 800,999 & -0.015 & 601,000 & 700,999 & -0.018 \\
\hline 801,000 & 900,999 & -0.025 & 701,000 & 800,999 & -0.020 \\
\hline 901,000 & & -0.030 & 801,000 & 900,999 & -0.030 \\
\hline$\geq 1,000,001$ & & -0.035 & 901.000 & $1,000,000$ & -0.040 \\
\hline & & & \multicolumn{2}{|c|}{$\geq 1,000,001$} & -0.050 \\
\hline
\end{tabular}

Source: Adapted from Soares (2016) . 


\section{RESULTS AND DISCUSSION}

The assessment carried out by the questionnaire and following the milking processing in the initial phase of the study showed that the milkers had no adequate knowledge to proper operation and maintenance of the milking and cooling equipments, thus hampering the use and cleaning process of such equipments. The dairy fams profiles in this study are presented in Chart 2. 


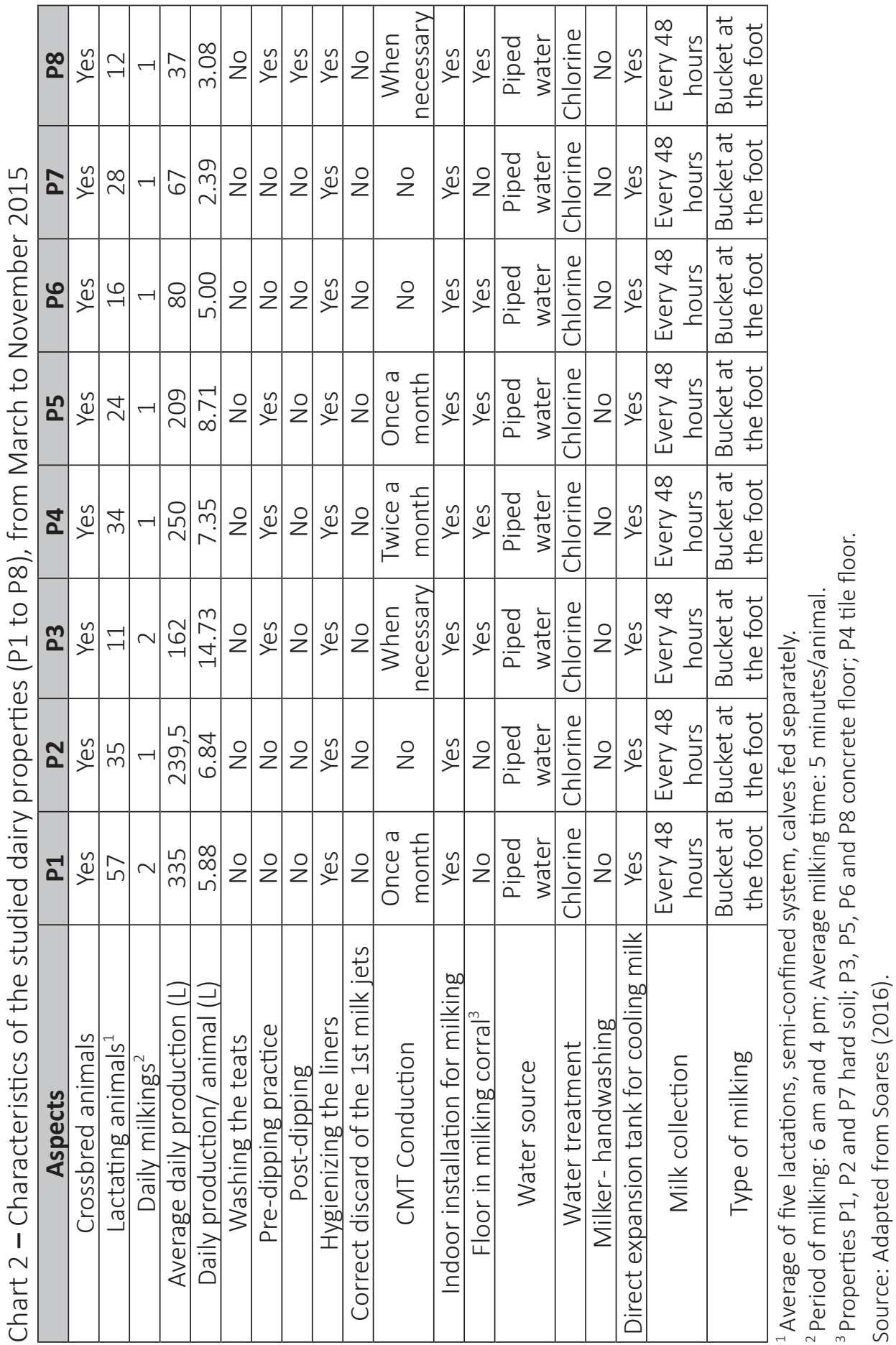


The milking was performed in covered and paved corral (62.5\%) or milking parlor (37.5\%). Lima (2007), in his study at the Zona da Mata Mineira, Minas Gerais State, Brazil, also found that most of the producer used paved and covered corral (66\%) or milking parlor (9\%), considered by the author as proper facilities to obtain milk. Two daily milkings was used by $25 \%$ of the properties, a practice that, according to Ferreira et al. (2007), helps prevent mastitis because the milk stays for a shorter period in the udder.

The practice of pre-dipping was not performed in $50 \%$ of the properties, the drying of the teats was performed with collective cloth towels in $37.5 \%$. The black mug test was not performed in $60 \%$, the first jets of milk was discarded on the ground in all the rural properties. The post-dipping was not performed in $87.5 \%$ and there was no milking line order established for animals with high SCC, and none of the properties had a mastitis control program or a proper tracking on the use of veterinary drugs. Milk residues were observed in the milking equipment and the expansion tank in 50\% of the properties, and the insufflators were worn and had cracks in 37.5\%.

Similar results to this study were verified by Neta (2015), which evaluated 34 rural properties in the city of Alegre, Espírito Santo State, Brazil. It was found that 53\% have hygienized teats and udders, 20\% had pre-dipping and $6 \%$ post-dipping. The habit of drying the udder and teats before milking was done by $53 \%$ of properties, $29 \%$ have used paper towels and $23 \%$ cloth towels. The test of black background mug for prevention of clinical mastitis was done by $24 \%$ of them while the other $76 \%$ did not adopted.

In the second stage, with the training on techniques of good milking practices performed, difficulties were found in the standardization of sanitizers' dilutions and the action time of the mixture on the surface in $33.3 \%$ of the producers, which could have compromised the quality of the milking and storage equipment sanitation. The old and unreformed facilities in $62.5 \%$ of the properties, especially in relation to floors, hindered the removal of waste and the cleaning, increasing the contamination risks in equipment, utensils, personal and animals. The test of black background mug, the practice of milking suspected animals at the end of the process and the measurement of the cooled milk temperature were adopted in all the properties. 
There was no statistical difference $(p>0.05)$ among the values of the physicochemical parameters from each property in the different months of evaluation, March and November 2015 (Table 1). Frauds were not found in the assessed samples and the milk composition data showed que all samples were in accordance with the standards required by the Brazilian legislation (BRASIL, 2011).

Table 1- Physicochemical characteristics of the evaluated milk.

\section{Properties}

\begin{tabular}{lrrrrrrrr} 
Parameters $^{*}$ & $\mathbf{P 1}$ & $\mathbf{P 2}$ & $\mathbf{P 3}$ & $\mathbf{P 4}$ & $\mathbf{P 5}$ & $\mathbf{P 6}$ & $\mathbf{P 7}$ & $\mathbf{P 8}$ \\
\hline Acidity $^{\circ} \mathrm{D}$ & 15.18 & 15.50 & 14.65 & 16.00 & 14.65 & 15.60 & 14.30 & 16.20 \\
Fat \% & 3.1 & 3.0 & 3.0 & 3.5 & 3.0 & 3.2 & 3.2 & 3.6 \\
Lactose \% & 4.55 & 4.57 & 4.45 & 4.59 & 4.54 & 4.50 & 4.54 & 4.25 \\
Protein \% & 3.36 & 3.22 & 3.37 & 3.53 & 3.38 & 3.35 & 3.22 & 3.42 \\
Cryoscopy $^{\circ} \mathrm{H}$ & -0.535 & -0.534 & -0.536 & -0.540 & -0.533 & -0.536 & -0.541 & -0.545 \\
DDE \% & 9.06 & 9.14 & 9.05 & 9.34 & 9.12 & 9.12 & 8.88 & 9.13 \\
TDE \% & 12.16 & 12.61 & 12.52 & 12.87 & 11.82 & 12.35 & 12.08 & 12.75 \\
Density g/mL & 1.033 & 1.033 & 1.032 & 1.033 & 1.033 & 1.033 & 1.032 & 1.033 \\
\hline
\end{tabular}

*Standards of Brazilian legislation: titratable acidity 15 to 18 oD; at least 3\% fat; at least 2.9\% protein; Cryoscopic index-0.530 to- 0.550 oH; Degreased Dry Extract (DDE) minimum 8.4\%; Total Dry Extract (TDE) minimum 11.4\%; Density at $15^{\circ} \mathrm{C}: 1.028$ to $1.034 \mathrm{~g} / \mathrm{mL}$. Source: Adapted from Soares (2016).

The determinations of the $\mathrm{NI}$ n. 62 (BRASIL, 2011) were used to evaluate TBC and SCC. The maximum counts allowed for raw refrigerated milk are $1 \times 10^{6} \mathrm{CFU} / \mathrm{mL}$ and $4 \times 10^{6}$ cell/mL, respectively, for the period of this study.

The results of TBC and SCC before and after training in good milking practices of all the properties are showed in Table 2. 
Table 2- Milk Total Bacteria Count (TBC) and Somatic Cell Count (SCC) of the dairy farms, before and after training on good milking practices.

\begin{tabular}{|c|c|c|c|c|c|c|}
\hline & \multicolumn{3}{|c|}{ TBC (log CFU/mL) } & \multicolumn{3}{|c|}{ SCC (log cell/mL) } \\
\hline & Before & After & Change \% & Before & After & Change \% \\
\hline \multicolumn{7}{|c|}{ Properties that had implemented all the good milking practices } \\
\hline P1 & $5.94 \mathrm{~b}$ & $4.23 \mathrm{a}$ & -28.73 & 5.33 a & $5.30 \mathrm{a}$ & -0.69 \\
\hline P2 & $5.13 b$ & $4.28 \mathrm{a}$ & -16.46 & $5.51 \mathrm{a}$ & $5.36 \mathrm{a}$ & -2.70 \\
\hline P3 & $4.71 b$ & $4.53 \mathrm{a}$ & -4.04 & $5.81 \mathrm{a}$ & $5.60 \mathrm{a}$ & -3.67 \\
\hline P4 & $5.97 b$ & $5.61 \mathrm{a}$ & -6.08 & 5.79 a & $5.72 \mathrm{a}$ & -1.16 \\
\hline P5 & $5.05 \mathrm{~b}$ & $4.02 \mathrm{a}$ & -20.38 & 5.45 a & $5.08 \mathrm{a}$ & -6.94 \\
\hline Mean & $5.36 \mathrm{~b}$ & $4.53 \mathrm{a}$ & -15.14 & $5.58 \mathrm{a}$ & $5.41 \mathrm{a}$ & -3.03 \\
\hline
\end{tabular}

Properties that had not implemented all the good milking practices

$\begin{array}{ccccccc}\text { P6 } & 4.50 \mathrm{a} & 5.36 \mathrm{~b} & +15.97 & 5.04 \mathrm{a} & 5.19 \mathrm{a} & +2.83 \\ \text { P7 } & 5.26 \mathrm{a} & 5.76 \mathrm{~b} & +8.67 & 5.26 \mathrm{a} & 5.18 \mathrm{a} & -1.53 \\ \text { P8 } & 5.84 \mathrm{~b} & 5.54 \mathrm{a} & +5.20 & 5.09 \mathrm{a} & 5.24 \mathrm{a} & +2.90 \\ \text { Mean } & 5.20 \mathrm{a} & 5.55 \mathrm{~b} & +9.95 & 5.13 \mathrm{a} & 5.20 \mathrm{a} & +1.40\end{array}$

${ }^{a b}$ Means followed by the same letter on the line, for each of the parameters analyzed (TBC and SCC), did not differ at $5 \%$ sgnificance.

Source: Adapted from Soares (2016).

Six properties (75\%), of the eight studied, showed reduction in TBC after the training. The average of these properties before was $6.02 \times 10^{6} \mathrm{CFU} /$ $\mathrm{mL}$ and after was $1.2 \times 10^{6} \mathrm{CFU} / \mathrm{mL}$, which represents $80.06 \%$ of reduction in the bacteria population. Other authors also evaluated the reduction in TBC count with the implementation of hygiene practices during milking. Vallin et al. (2009) had an average reduction of $86.99 \%$ comparing the averages before and after training and implementation of the good practices. A similar result was found by Bozo et al. (2013), comparing the average of dairy farms in Pitangueiras city, Paraná State, Brazil, they found an average reduction of $93.4 \%$ for TBC.

All properties had scores above the limit prescribed by Brazilian law for TBC before training. After the training and adoption of at least some of the good practices in the milking routine, only two of these properties continued above the limit of bacteria counts.

Even with average reduction during the period of this study, it was observed that the average TBC and SCC were significantly higher $(p<0.05)$ 
in the rainy season (spring and summer) for the farmers that have not implemented all the proposed practices. Similar results were described by Roma Jr. et al. (2009), when analyzing samples of milk cooling tanks over 12 months, they found the highest values for SCC and TBC in the rainy season. These results may be associated with the stress to high temperatures and the humidity, which can increase incidence of infections and the number of pathogens which cows are exposed.

Moreover, these results can also be attributed to the resistence of some milkers to use all the guidelines on hygienic milking and the difficulty to train some of them to perform the good practices in the properties.

Thus, in high humidity periods, dairy farmers must adopt more intense strategies in environmental hygiene and management at the time of milking in order to do not compromise the quality of your product. The establishment of good milking practices, maintenance and cleaning of the equipment, permitted a reduction in TBC in the five properties that have implemented all the good practices, even in a period with increase in rainfall, thus improving the quality of milk delivered to the industry.

Concerning SCC, it was observed that the average decreased, but there was no statistically significant difference $(p<0.05)$ when it confronted the results before and after the training in good milking practices. Possibly, the results of that implementation will be seen better in the next lactation, after drying the animals.

The practices that prevent mastitis are largely the same to avoid contamination of the milk. Cleaning and sanitization pre and post-milking are able to reduce the milk TBC in $98 \%$ on the first day of the implementation of good practices (SILVA et al., 2011). Although, it is known that the SCC response to the implementation of good practice is not as immediate and significant as the TBC, since it is necessary to adopt other specific practices for reducing the SCC, such as correct management of sick animals, treatment of mastitis and, sometimes, discarding animals with recurring mastitis, among others (BELOTI et al., 2012).

Mastitis often affects more pure breed high producing animals. As the SCC is an indicator of the mammary gland health, it was expected that the milk produced in the studied region presented low scores in this regard, 
since the animals that make up the herd this region are predominantly crossbred and of low production (SANTOS; FONSECA, 2007). Thus, the payment for quality programs are the most efficient way to get results in the implementation of good practices in milking with the producers (BATTAGLINI et al., 2013).

A simulation of the payment by the industry to these producers during the period of the study were done to check the influence of the adoption of the good milking practices on the economic aspect. The calculated values of the bonus/discount per liter of milk and the total values (in R\$), based on TBC and SCCC before and after the training and implementation of the good practices, are shown in Table 3. Assuming that the production systems of the properties were very similar in terms of production costs and potential during the study, it was seen a significant impact on the milk quality and, consequently, on the final price received. Moreover, there were no effective increase in the costs at the properties, only a better use of their resources. 


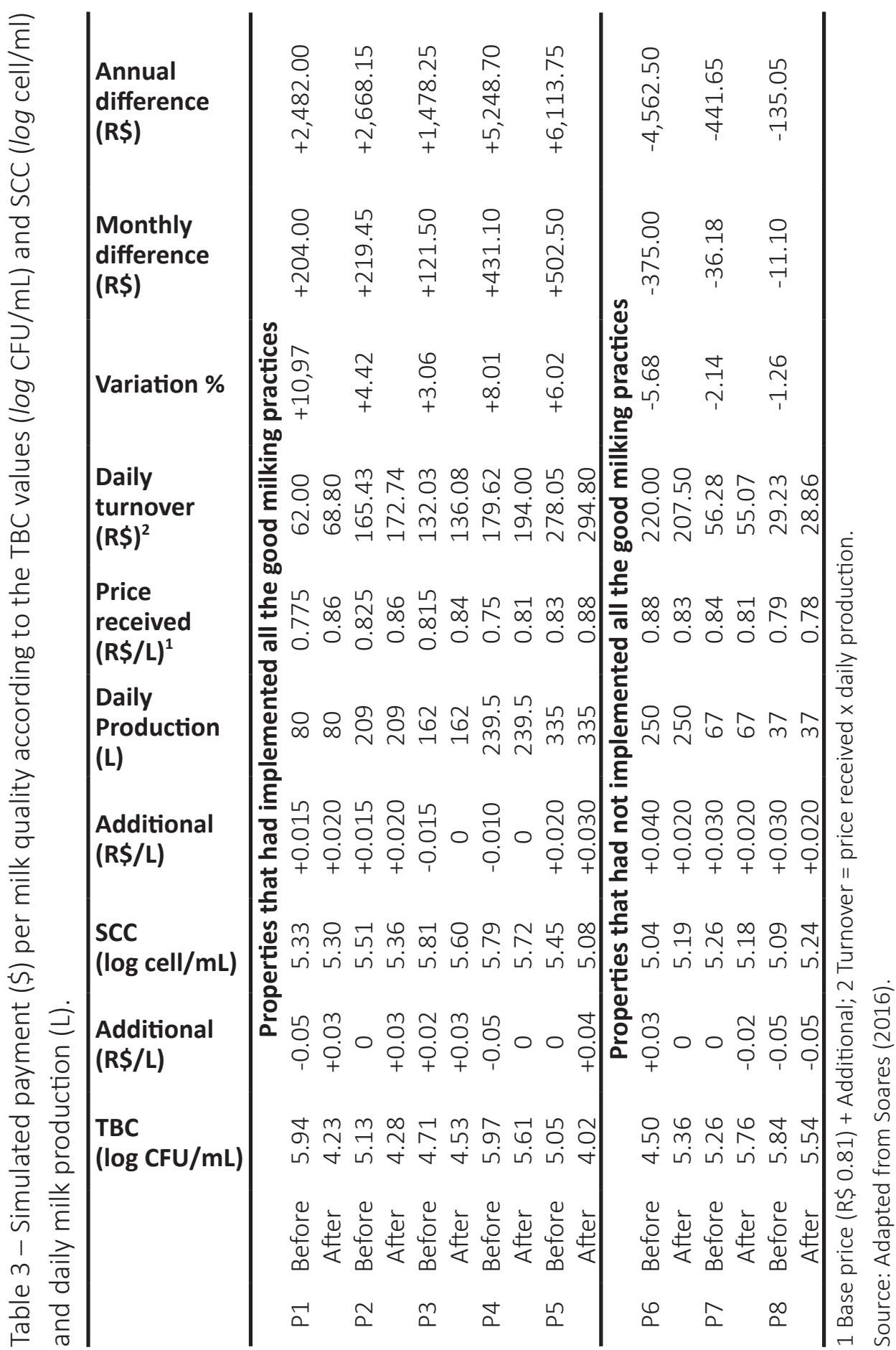


The property one (P1) obtained the highest increase (11\%) in the percentages of bonus paid by the industry after the implementation of hygiene practices during milking, compared with the others. Among all the evaluated properties, P5 achieved reductions of $75 \%$ in TBC and $9.25 \%$ in SCC, what would represent an annual increase in income of $R \$ 2,482.00$. A propertie that also implemented the good practices, $\mathrm{P5}$, would receive the highest price/liter ( $\mathrm{R} \$ 0.88$ ) after training, showing the best milk related to TBC and SCC, and the largest annual increase, $R \$ 6,113.75$, due its bigger daily production compared to the others.

When it was compare the average price paid for milk quality to the two groups of properties (P1-P5 and P6-P8), it is apparent that there is a significative difference. The first group change the received from $\mathrm{R} \$ 0.799$ to 0.850 /liter while the second group chance from $\mathrm{R} \$ 0.837$ to 0.807 , representing a total difference of $\mathrm{R} \$ 29.59 /$ year/liter between them. These values (Table 3 ) comproved that the full adoption of the goof milking practices significantly reduced TBC and SCC, which provided increased of milk quality, mastitis control in the herd and bonus received, resultin in additional values in the final income of the producers. This situation did not occur in properties P6, P7 and P8. They had an increase in their TBC and the SCC, probably due the rainy season, and received penalties in the milk price, which affected their total income.

Thus, there was a positive financial result due the payment by better milk quality properties for those producers who have implemented all the proposed good milking practices and this profit could be converted into new purchases and improvements of animals, products and technologies.

\section{CONCLUSION}

The data indicate significant improvement in the health of the mammary gland and the microbiological quality of the milk on the properties that have implemented good milking practices after a specific training, which represented the majority of the farms studied. This shows that such practices are essential for adaptating the properties and improving the milk quality regarding the parameters set by the Brazilian 
legislation and used by the industry to pay the producers. Moreover, from an economic point of view, it can seen a positive impact of the good practices on the price received when a payment for milk quality was simulated, considering TBC and SCC. This increase in profit with the maintenance of good milking practices, over time, could be invested in new technologies in the properties.

Thus, the inclusion of good practices in the milking management promotes positive impacts on quality and socioeconomic aspects, reducing milk discard due low quality, improving the yield in the industry and allowing an increase in the income of the milk producers. All of them end up helping the maintenance of these rural properties running and in the dairy field, providing even greater growth in the economic activity at the area.

\section{Acknowledgement}

The authors thank CAPES and FUNDECT for the financial support.

\section{REFERENCES}

BATTAGLINI, A. P. P.; FAGNANI, R.; DUNGA, K. S.; BELOTI, V. Difusão de boas práticas e caracterização de propriedades leiteiras. Arquivo Brasileiro de Medicina Veterinária e Zootecnia, Belo Horizonte, MG, v. 62, n. 237, p. 151-54, Mar. 2013.

BELOTI, V.; RIBEIRO JÚNIOR, J. C.; TAMANINI, R.; SILVA, L. C. C. Impacto da implantação de boas práticas de higiene na ordenha sobre a qualidade microbiológica e físicoquímica do leite cru refrigerado. Revista do Instituto de Laticínios "Cândido Tostes", v. 67, n. 388, p. 5-10, Sept./Oct. 2012.

BENTLEY INSTRUMENTS. Bactocount 150: operator's manual. Chaska, EUA: Bentley Instruments, 2004. 35p.

BENTLEY INSTRUMENTS. Somacount 150: operator's manual. Chaska, EUA: Bentley Instruments, 1994. 77p.

BOZO, G. A.; ALEGRO, L. C. A.; SILVA, L. C.; SANTANA, E. H. W; OKANO, W.; SILVA, L. C. C. Adequação da contagem de células somáticas e da contagem bacteriana total em leite cru refrigerado aos parâmetros da legislação. Arquivo Brasileiro de Medicina Veterinária e Zootecnia, Belo Horizonte, MG, v. 65, n. 2, p. 589-94, 2013. 
BRASIL. Ministério da Agricultura, Pecuária e Abastecimento. Instrução Normativa n. 62 de 29 de dezembro de 2011. Regulamento Técnico de Produção, Identidade e Qualidade do Leite tipo A, de Leite Cru Refrigerado, de Leite Pasteurizado e o Regulamento Técnico da Coleta de Leite Cru Refrigerado e seu Transporte a Granel, em conformidade com os Anexos desta Instrução Normativa. Diário Oficial [da] República Federativa do Brasil, Brasília, DF, Section 1, p. 13.

BRASIL. Instrução Normativa n. 68 de 12 de dezembro de 2006. Oficializa os Métodos Analíticos Oficiais Físico-Químicos, para Controle de Leite e Produtos Lácteos, em conformidade com o anexo desta Instrução Normativa, determinando que sejam utilizados nos Laboratórios Nacionais Agropecuários. Diário Oficial da União, Brasília, 14 Dec. 2006. Section 1, p. 8.

BRASIL. Ministério da Saúde. Secretaria de Vigilância Sanitária. Portaria n. 368, de 4 de setembro de 1997. Aprova o regulamento técnico sobre as condições higiênico-sanitárias e de boas práticas de fabricação para estabelecimentos/ industrializadores de alimentos. Diário Oficial [da] União, Brasília, 8 Sept. 1997. Section 1, p. 19697.

CEPEA. Excesso de chuva no Sul e falta no Nordeste prejudicam produção. Boletim do Leite, Piracicaba, SP, year 21, n. 247, Dec. 2015. Available in: https://www. cepea.esalq.usp.br/upload/revista/pdf/0655987001468844009.pdf. Access in: Mar. 2016.

FERREIRA, J. L.; LINS, J. L. F. H. A.; CAVALCANTE, T. V.; MACEDO, N. A.; BORJAS, A. L. R. Prevalência e etiologia da mastite bovina no município de Teresina, Piauí. Ciência Animal Brasileira, Goiânia, GO, v. 8, n. 2, p. 261-6, Apr./June 2007.

LIMA, L. L. Características da produção e qualidade do leite cru na Zona da Mata de Minas Gerais. 2007. 51f. Dissertação (Mestrado em Medicina Veterinária) Universidade Federal de Minas Gerais (UFMG), Belo Horizonte, 2007.

NETA, F. C. N.; JUNQUEIRA, M. S.; CARNEIRO, J. C. S.; RAMOS, M. P. P.; ABDALLAH, F. R.; FRACALOSSI, C. P. Condições de produção de leite em propriedades familiares localizadas no município de Alegre - ES, Brasil. Revista do Instituto de Laticínios "Cândido Tostes", Juiz de Fora, MG, n. 3, v. 70, p. 117-31, May/June 2015.

ROMA JÚNIOR, L. C.; MONTOYA, J. F. G; MARTINS, T. T.; CASSOLI, L. D.; MACHADO, P. F. Sazonalidade do teor de proteína e outros componentes do leite e sua relação com programa de pagamento por qualidade. Arquivo Brasileiro de Medicina Veterinária e Zootecnia, Belo Horizonte, MG, n. 6, v. 61, p. 1411-8, Dec. 2009. 
SANTOS, M. V.; FONSECA, L. F. L. Estratégias para controle de mastite e melhoria da qualidade do leite. São Paulo: Manole, 2007. 314p.

SILVA, L. C. C.; BELOTI, V.; TAMANINI, R.; OVIDIO, L.; MATTOS, M. R.; ARRUDA, A. M. C. T.; PIRES, E. M. F. Rastreamento de fontes da contaminação microbiológica do leite cru durante a ordenha em propriedades leiteiras do Agreste Pernambucano. Semina: Ciências Agrárias, Londrina, PR, v. 32, n. 1, p. 267-76, Jan./Mar. 2011.

SOARES, E.S.M. Application of good milking practices: economic impacts and bovine raw milk quality. 2016. 47 f. Dissertação (Mestrado)- Faculdade de Medicina Veterinária e Zootecnia, Universidade Federal de Mato Grosso do Sul, Campo Grande, MS, 2016.

VALLIN M. V.; BELOTI, V.; BATTAGLINI, A. P. P.; TAMANINI, R.; FAGNANI, R.; ANGELA, H. L.; SILVA, L. C. C. Melhoria da qualidade do leite a partir da implantação de boas práticas de higiene na ordenha em 19 municípios da região central do Paraná. Semina: Ciências Agrárias, Londrina, PR, n. 1, v. 30, p. 181-8, Jan./Mar. 2009. 
